\title{
薄膜パラメトロンを用いたフェイルセイフ素子†
}

\author{
伊藤＼cjkstart登・池野和夫・五郎川 達・高田 勝 \\ 大井電気株式会社 横浜市港北区璘名町 884-1 \\ (昭和 45 年 8 月 14 日 受付)
}

\section{Fail Safe Element Using Thin Film Parametron}

\author{
Noboru Ito, Kazuo Ikeno, Tohru Gorokawa and Masaru Takada \\ (Laboratory, Oi Electric Co. Ltd, Yokohama) \\ (Received August 14, 1970)
}

The high speed fail safe element is an urgent need of the day, especially in the field of traffic control such as that used on a railway or a highway. This is because the present magnetic relay control system widely used in the market may become unsatisfactory as the required control speed is drastically increasing. Few kinds of electronic fail safe elements have been reported, one is the fail safe threshold logical operational oscillator using resistors and semiconductors whose output voltages $+V$ and $-V(|V|>$ threshold voltage) correspond to the truth values 1 and 0 respectively, and the voltage less than the threshold voltage corresponds to the truth value $1 / 2$. Another is the subharmonic oscillator called parametron whose 0 and $\pi$ correspond to the truth values 0 and 1 respectively. The failure of an element and a circuit resulting in no voltage is covered by the following element whose constant signal is always monitored. The operational oscillator is excellent in the idea but the element is complicated and expensive, the subharmonic oscillator is simple but large in size and slow in speed because of the ferrite core.

Here aiming at accuracy, high speed, small size and low cost, we haved eveloped a thin permalloy film parametron to replace the ferrite parametron. The permalloy film is deposited onto a piece of phosphorous bronze wire $0.47 \mathrm{~mm}$ in dia.. The film is $1 \mu \mathrm{m}$ thick and has a composition of $81 \mathrm{Ni}-\mathrm{Fe}$ with uniaxial anisotropy in circumference, and the anisotropy magnetic field is about 200 $\mathrm{AT} / \mathrm{m}$. To investigate the quality, we built a fail safe control equipment using 325 thin film parametron elements and 28 magnetic control relays. As a result of this study, we find the fail safe element using thin film parametron is very accurate under a clock frequency of $50 \mathrm{kHz}$ and is cheap and small.

\section{1. ま えがき}

電車，エレベータなど交通機関のブレーキは，運転 時, 電力によって開き, 電気を切ればスプリングの力 などで自動的にブレーキが閉じるようになっている. これが逆に，電力でブレーキを閉じる構造であれば， 停電によりブレーキは作動しなくなり，運転の自由を 失って暴走する。これはフェイルセイフが実際に応用

$\dagger$ 電子通信学会全国大会 $($ 昭 $44 \cdot 10$ ), 電気関係東北支部 連合大会（昭 $44 \cdot 10 ）$ で発表
されている一例で，これに類することはかなり古くか ら常識的に行なわれていた。 また如上機器の制御には 電磁継電器を使用するが，これも重力またはスプリン グを利用して，停電または励磁巻線の断線にさいして は復帰する構造になっている。すなわち異常事態にさ いしては, 絶対に制御イオン側に素子が働いてはなら ないのである.

さて時代の進歩とともに, 制御機能は複雑に, かつ その速度は高速化してきた. かくして今までの制御素 子の主役である電磁継電器では, この時代の要求に応 
ずることができず，これに代わる新しい素子が研究ざ れるにいたった，代表的な例として，トランジスタを 利用したものと市，フェライトパラメトロンを利用し た子のう，3）が報告されている．前者はトランジスタ発 振器の出力を整流して得た電圧 $(2 \mathrm{~V})$ を直流電圧 $(-$ V) 飞重量, $+V$ 真理値 1 亿, また無入力時の電圧 $(-\mathrm{V})$ を真理值 0 亿対応させ，また構成部品の故障は 発振停止 $(-V)$ または電圧減（閾値以下の電圧）之 なり，真理值は 0 またはたかだか $1 / 2$ となる。

さらに双対の関係にある正副の二重系の各段出力を exclusine OR 回路でチェックし, 故障点を表示して いる. 後者はフェライトパラィトロンの発振位相 $(0$,

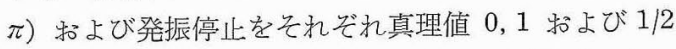
飞対応させ，また論理回路は 0 系，1系（異常のさい はそれぞれ0相， $\pi$ 相に安定する系）の二重系を採用， 素子の故障または布線断は, この双対二重系の不一致 として検出している.いずれるフェイルセイフ素子と しての機能は備えているが, 前者は複雑高価であり, 後者は廉価であるが論理速度が遅く（現在クロック周 波数 $5 \mathrm{kHz})$ ，大形，かつプリント化に適さないなど の欠点があった。

われわ机は上記フェライトパラメトロンの欠点を改 良する意味で，燐青銅線上にパーマロイを電着した， 1 軸異方性を有する薄膜磁性線を用いてパラメトロン を製作，フェイルセイフ素子として使用した試作機に よって検討した結果, クロック周波数 $50 \mathrm{kHz}$ で非常 に安定作動することを確認した。

\section{2. 薄 膜 磁 性 線 ${ }^{4)}$}

分周波発振5のリアクター材である磁性膜は 0.47 $\mathrm{mm}$ 径の憐青銅線上飞, Table 1 の条件で磁場中電着 により製作される。この磁場は線に直接流される電流 によって与克られ，したがって結晶異方性は円周方向 そ生ずる. 組成は磁わい最小の点である $81 \mathrm{Ni}-\mathrm{Fe}$ に

Table 1 Composition and conditions of permalloy electrolyte

\begin{tabular}{lc}
$\mathrm{NiSO}_{4}: 7 \mathrm{H}_{2} \mathrm{O}$ & $230.0 \mathrm{~g} / \mathrm{l}$ \\
$\mathrm{FeSO}_{4} \cdot 7 \mathrm{H}_{2} \mathrm{O}$ & $5.5 "$ \\
$\mathrm{H}_{3} \mathrm{BO}_{3}$ & $30.0 "$ \\
$\mathrm{Na}_{2} \mathrm{P}_{2} \mathrm{O}_{2}$ & $0.2 "$ \\
$\mathrm{NaC}_{6} \mathrm{H}_{4} \mathrm{CONHSO}_{2}$ & $0.2 "$ \\
$\mathrm{CuSO}_{4} \cdot 5 \mathrm{H}_{2} \mathrm{O}$ & $0.3 "$ \\
$\mathrm{NiCl}_{2} \cdot 6 \mathrm{H}_{2} \mathrm{O}$ & $16.0 "$ \\
$\mathrm{H}_{2} \mathrm{SO}_{4}$ & $0.3 \mathrm{cc} / \mathrm{l}$ \\
$\mathrm{pH}$ & 2.1 \\
bath tempetature & $47 \pm 1.0{ }^{\circ} \mathrm{C}$ \\
current density & $50.0 \mathrm{~mA} / \mathrm{cm}^{2}$ \\
magnetic field & $1600.0 \mathrm{AT} / \mathrm{m}$ \\
\hline
\end{tabular}

調整され，膜厚は $1 \mu \mathrm{m}$ である。すた現在得られる電 着膜の異方性磁界は $200 \mathrm{AT} / \mathrm{m}$ 程度である。

\section{3. 素子の構造・特性}

前記の磁性線上に, 発振巻線（1）, 定数巻線（2）, 情報巻線（3），（4）学施乙，癹振卷線に並列に同調 容量 $C$ を付加したるのを1素子副とする. Fig. 1 にこ

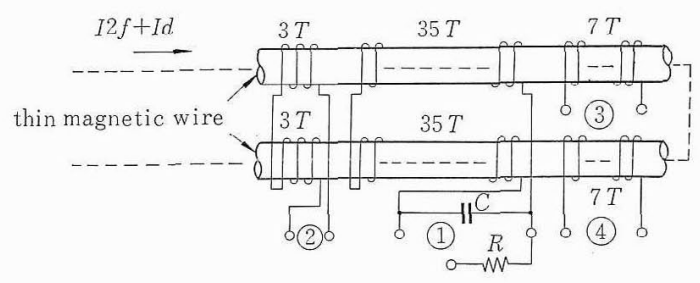

Fig. 1 Construction of a fail safe element using thin film parametron, when exciting frequency is $6 \mathrm{MHz}$

の状態を示す磁性線 2 本を可行に用いたのは外部騒乱 の影響を除くためである. Fig. 2 は試作品の写真で,

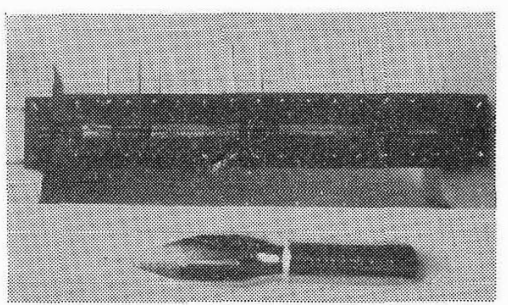

Fig. 2 Photograph of three thin film fail safe elements on one substrate

3 素子が 1 基台に実装され，各巻線間はスペーサで保 たれて蛒り，また同調容量は裏面に配置されている。 大ささは幅 $10 \mathrm{~mm}$, 長さ $64 \mathrm{~mm}$, 厚み $15 \mathrm{~mm}$ で, 結合抵抗はプリント板に実装される.

以下にまず素子単体としての電気的特性について述 ベ上う，文献 5）にくわしく述べる上らに，分周波発 振は同調点で最も発振しやすく，容量を変克て離調す ると従い多くの励振電流 $I_{2 f}$ 必要とする。離調はま たバイアス電流 $I_{d}$ を変化させても起こりらる．一般 に $I_{d}$ の上下限の広がりの大なるほど素子として安定 であるので，この領域をマージン特性と称し性能比較 に用いられる。 また本交老通じ励振周波数 $(2 f)$ は 6 $\mathrm{MHz}$ に固定, クロック Duration は1:1なるよう 調整した，また標準負荷抵抗 $R_{0}$ は $1 \mathrm{k} \Omega$ とした，た だし被測定素子への結合抵抗は $2 R_{0}$ すなふらら種情報 定半分に減じて行なった。

Fig. 3 は $I_{d}=0.1 \mathrm{~A}$ 江設定, 容量 $C$ の変化に対す る最低励振電流 $I_{2, f}$ の值を実測したもので，パラヌー ターはクロック周波数である. 図から $I_{2 f}=0.18 \sim 0.2$ 


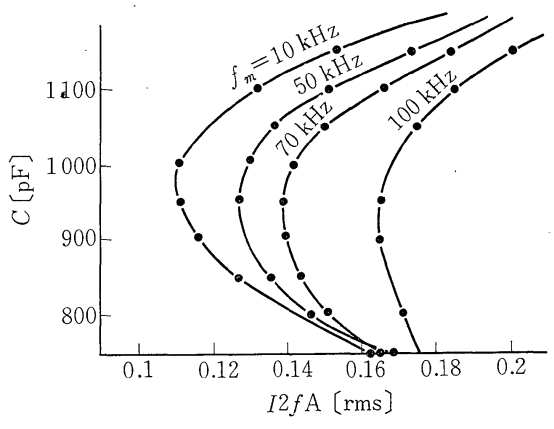

Fig. 3 Detuning capacity $C$ vs. exciting current $I_{2 f}$ characteristic curves of the thin film fail safe element for the parameter of clock frequency $f_{m}$, when bias direct current $I_{d}$ is $0.1 \mathrm{~A}$

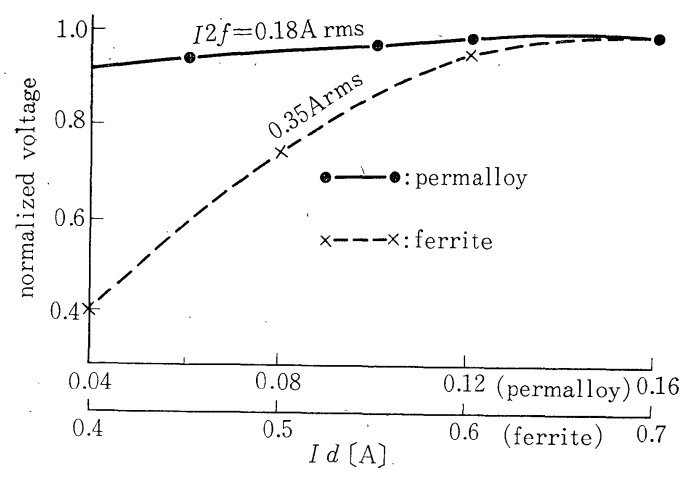

Fig. 4 Normalized oscillatory voltage vs. bias direct current characteristic curves of the thin film (solid line) and ferrite (dashed line)fail safe element, when $f_{m}=50 \mathrm{kHz}$

A (rms) で使用すれば，単体としてはクロック周波数 $100 \mathrm{kHz}$ まで許容しらることがわかる. しかし他の条

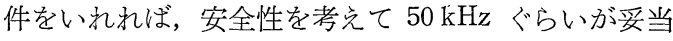
な所であろう. Fig. 4 にクロック周波数 $50 \mathrm{kHz}$ (以 下同一条件につき省く）の場合の，直流バイアス $I_{d}$ に対する規準化発振電圧特性を示した. 比較のためフ ェライトパラメトロン (PM-4) の特性をそう入した が，薄膜パラメトロンのほうがはるかに定電圧性が良 いことがわかる：これは多数決論理素子としては最良 の特色であり，同時に定数監視を要するフェイルセイ フ素子としてもたいへん好都合なことである。

Fig. 5 は励振電流 $I_{2 f}$ 変化に詨する規準化発振電 圧特性で，この場合もフェライトパラメトロンより定 電圧性が非常にすぐれている，Fig. 6 に温度に対する $I_{d}$ マージン特性を示した. パーマロイの温度特性 $(+)$ をスチロールコンデンサのそれ（一）で補償している ので, 同調点の $I_{d}$ 方向の移動は見られない。この素 子は温度に対して非常に安定であることが図から明ら

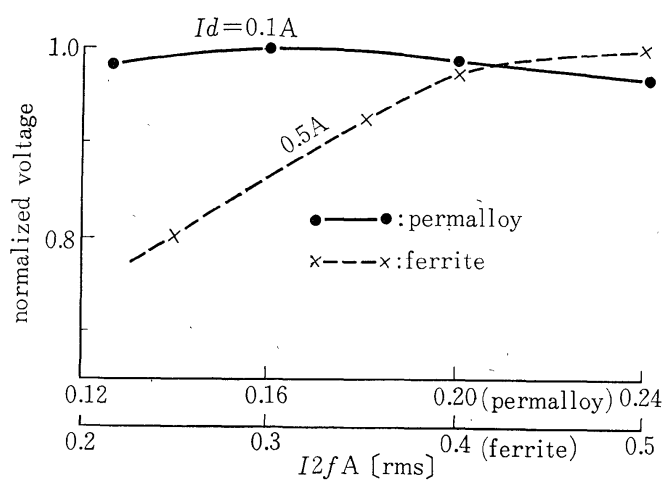

Fig. 5 Normalized oscillatory voltage vs. exciting current characteristic curves of the thin film (solid line) and ferrite (dashed line) fail safe element, when $f_{m}=50 \mathrm{kHz}$

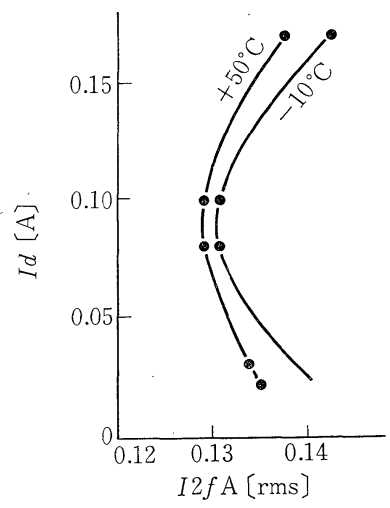

Fig. $6 I_{d}$ vs. $I_{2 f}$ margin characteristic curves of the thin film fail safe element for the parameter of temperature, when $f_{m}=$ $50 \mathrm{kHz}$

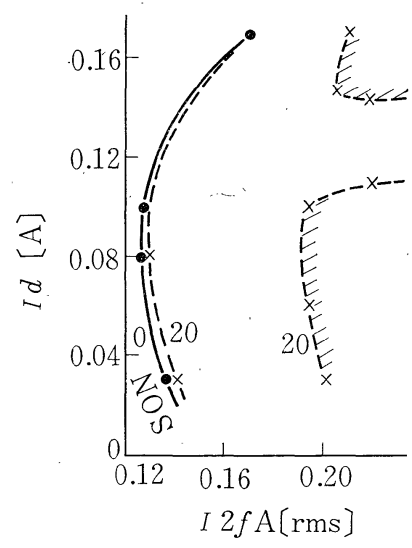

Fig. $7 I_{d}$ vs. $I_{2 f}$ margin characteris. tic curves of the thin film fail safe element for the number of sons, when $f_{n}=50 \mathrm{kHz}$

かである. Fig.7 に標準状態における子供 (fan aut) の影響を示している. 子供の数 20 個になると $I_{2 f}$ の 大なる汇ら（図中斜線部分）で誤動作するので，その 数は 15 ぐらいに押さえた汪らがよい。ただしクロッ ク周波数を $50 \mathrm{kHz}$ より高くしたい場合は, 子供の数 を上述より減少させなければならない。これは Fig. 3 执よび Fig.7 から明らかなように，クロック周波数 あるいは子供の数の増大は, マージン特性の安定領域 
を著しく狭めるからで, 逆に子供の数が少ない場合は, クロック周波数を標準值より増加しうる。またその逆 も成り立?.

\section{4.フェイルセイフ機能}

フェイルセイフ性を保つため，上記素子は 2 值的な 障害に対し, 正常状態出力を発生するか, あるいは定 められた論理值に誤らない，すなうち安全側の故障状 態出力を発生するものでなければならない。

さて上記素子は発振電圧の位相一一すわら $0, \pi$ の 2 值一一情報源とするものであり，また Fig. 4， Fig. 5 に見るように外部要因に対し定電圧性が高いた め, その故障は出力電圧ゼロで特長つけられ, 中間值が ない、すなわちこの素子は 0 相， $\pi$ 相の有限電圧和よ び故障（配線断を含む）に対応するゼ口電圧の 3 つの 場合しか採り得ない典型的な 3 值形を有する.さらに, 正常状態（高エネルギ）の 2 值は, 故障状態（低エネ ルギ）に対し完全に対称位置にあり，0 相， $\pi$ 相のい ずれを論理的安定状態に対応させることも可能で，こ の点が他の現存素子（たと学ば電磁継電器, トランジ スタ）と異なり，双対の論理構成を容易にする理由で ある.このらち 0 相を論理安定状態とするものを 0 系, $\pi$ 相に対するものを 1 系とし，異常のさいはそれぞれ 0 相, $\pi$ 相に安定する 2 系の論理回路を作成, それら 2 系のANDをとって制御を行なわせ，異常状態は両 系の不一致として検出する．Table 2 はこの素子を用

Table 2 Values and signs of constant of the thin film fail safe paramatron constructing twin system, where the right column is for general use

\begin{tabular}{|c|c|c|c|}
\hline logic system & 0 & 1 & general \\
\hline delay & & & \\
\hline NOT & & & \\
\hline AND & & & \\
\hline OR & & & \\
\hline
\end{tabular}

いて，0系，1亲のフェイルセイフ機能を実現するた めの論理素子構成である，表中，円内の数字は，前段 からの正規情報電流を1とした場合の定数電流の大い さと，その位相（0相が “一”に， $\pi$ 相が “+”に対 応）を示している.右端に一般論理素子として使用する 場合の定数值を参考のため記載した。 また Table 2 構成に対する多数決論理值を Table 3 (a), (b), （c）に揭げた. Table 3（b）AND についてじゃっ か九説明を加觉れば，一般論理素子に対しては, Fig. 1
Table 3

(a) Majority table on normal and abnormal states of a input for the Delay logic in table 2

\begin{tabular}{c|c|c|c|c|c|c}
\hline sys. & \multicolumn{2}{|c|}{0} & \multicolumn{2}{c|}{1} & \multicolumn{2}{c}{ general } \\
\cline { 5 - 7 } fault & nor. & one & nor. & one & nor. & one \\
\hline-1 & $-3 / 2$ & $-1 / 2$ & $-1 / 2$ & $1 / 2$ & -1 & ※ unde. \\
\hline 1 & $1 / 2$ & $-1 / 2$ & $3 / 2$ & $1 / 2$ & 1 & unde. \\
\hline
\end{tabular}

(b) Majority table on normal and abnormal states of inputs for the AND logic in table 2

\begin{tabular}{|c|c|c|c|c|c|c|c|c|c|}
\hline sys. & \multicolumn{3}{|c|}{0} & \multicolumn{3}{|c|}{1} & \multicolumn{3}{|c|}{ general } \\
\hline input & nor. & one & both & nor. & one & both & nor. & one & both \\
\hline $\begin{array}{l}-1 \\
-1\end{array}$ & $-7 / 2$ & $-5 / 2$ & $-1 / 2$ & $-5 / 2$ & $-3 / 2$ & $1 / 2$ & -3 & -2 & $\begin{array}{l}-1 \\
\text {. }\end{array}$ \\
\hline $\begin{array}{l}1 \\
1\end{array}$ & $1 / 2$ & $-1 / 2$ & $-1 / 2$ & $3 / 2$ & $1 / 2$ & $1 / 2$ & 1 & unde. & -1 \\
\hline $\begin{array}{r}1 \\
-1\end{array}$ & $-3 / 2$ & $\begin{array}{l}-5 / 2 \\
-1 / 2\end{array}$ & $-1 / 2$ & $-1 / 2$ & $\begin{array}{c}-3 / 2 \\
1 / 2\end{array}$ & $1 / 2$ & -1 & $\begin{array}{c}-2 \\
\text { unde. } \\
※\end{array}$ & -1 \\
\hline
\end{tabular}

(c) Majority table on normal and abnormal states of inputs for the OR logic in table 2

\begin{tabular}{|c|c|c|c|c|c|c|c|c|c|}
\hline sys. & \multicolumn{3}{|c|}{0} & \multicolumn{3}{|c|}{1} & \multicolumn{3}{|c|}{ general } \\
\hline input & nor. & one & both & nor. & one & both & nor. & one & both \\
\hline $\begin{array}{l}-1 \\
-1\end{array}$ & $-3 / 2$ & $-1 / 2$ & ${ }_{1 / 2}^{()_{1}}$ & $-1 / 2$ & (2) $1 / 2$ & () $3 / 2$ & -1 & $\begin{array}{l}※ \\
\text { unde. }\end{array}$ & ${ }_{1}$ \\
\hline $\begin{array}{l}1 \\
1\end{array}$ & $5 / 2$ & $3 / 2$ & $1 / 2$ & $7 / 2$ & $5 / 2$ & $3 / 2$ & 3 & 2 & 1 \\
\hline $\begin{array}{r}1 \\
-1\end{array}$ & $1 / 2$ & \begin{tabular}{|c|}
$-1 / 2$ \\
$3 / 2$
\end{tabular} & $1 / 2$ & $3 / 2$ & $\begin{array}{l}1 / 2 \\
5 / 2\end{array}$ & $3 / 2$ & 1 & $\begin{array}{c}\text { unde. } \\
2\end{array}$ & 1 \\
\hline
\end{tabular}

の巻線（2）に定数 -1 が，ま炎巻線 (3)，(4) に ともに信号 +1 が流れる場合を考光ると，入力多数決 は+1となり，この素子は $\pi$ 相発振を行ない，正解と なる，次に巻線（3）または（4）が断線すると，入 力は $+1,-1$ の和でゼロとなり，発振位相は不定と なる。しかし 0 相を非制御側と考える限り，この不定 性は，正解 +1 に一致するか，または安定状態にある かで，実害はない。しかし巻線（3)，（4）にそれぞ れ $+1,-1$ が流れる場合に，巻線（4）が断線する と，前同様発振は不定となり，わずかでも十信号が大 であると $\pi$ 相発振を起こし，制御は GO となる．この 場合正解はー1，すなわら NOTGO であるから，この 場合の不定さは危険である。よってこのような不定さ には※印を付す．以上のことから一般論理素子はフ ェイルセイフ性がないといえる，ここで表左側 0 系・ 
1 系の AND を考学ると，両巻線断に対してはすべて 不一致, 片巻線断または両者混合の場合には, 不一致 かあるいは非制御状態となり，完全にフェイルセイフ 性を保障する. Table 3(a), (cc) についても同じこ とがい光る (NOT は Delay に含む)，ただ問題にな るのは，Table 3（c）飞（）印を付した場合，すなわ ち入力 $-1,-1$ で, 0 系の両巻線断となり, 同時飞 1'系の片巻線または両巻線が断線した場合で，正解は 0 相発振であるともかかわらず，この素子は $\pi$ 相発振 となり不都合である。よって論理設計ではこの点を検 討し，かつ上記の同時障害が起こらないよう，実装面 では，0 系，1系は完全に分離，電源関係も別にする。 さらに Table 2 円内の定数はフェイルセイフの生命 であるので，その変動はとくに監視され，異常のさい はアラームを出し制御は阻止される。これに関しては 次章に述べる.

さて一例として，Fig. 8 に 2 進 2 けたカウンタのフ

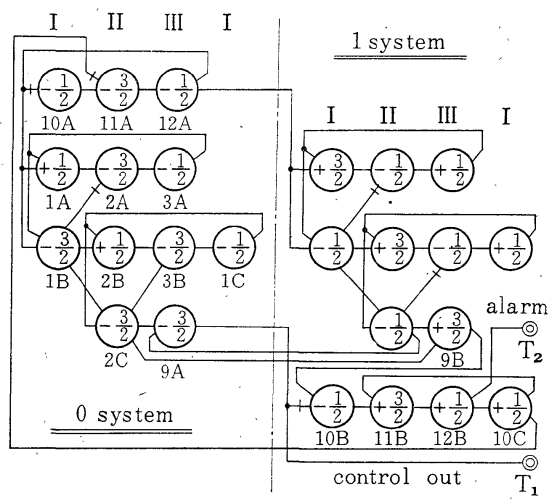

Fig. 8 Twin logic fail. safe construction of two digits binary counter using the thin film parametron

エイルセイフ構成を示す，正常状態では，0系・1系 のカウンタは一致し, ペラメトロン $9 \mathrm{~A}$ に出力があ り，端子 $T_{1}$ から制御情報を送出する.もし 0 系の素 子 $2 \mathrm{~A}$ の出力線が断線した場合, 素子 $3 \mathrm{~A}$ は自身の 定数 $-1 / 2$ 亿より以後常に 0 発振を行ない，したがっ て素子 $1 \mathrm{~B}$ 以下はすべて 0 発振となる。このとき， 1 系側から出力 1 があれば，0 系出力と一致せず，素子 の $9 \mathrm{~A}$ の出力は失われ，素子 $9 \mathrm{~B}$ に出力 1 が現われ， 次段のフリップフロップを1にセットし，端子 $\mathrm{T}_{2}$ か らアラーム情報を送出する。 さらに 1 系側の故障で, 出力 1 が現われなければ，制御信号も出ないし，アラ 一ムも出ないが，ともかくフェイルセイフである．逆 の場合も同様である.

ここで前述した Table 3 （c） ○印の場合を検討し てみよう。 0 系 2 B の 2 入力断を考学る.信号出力は
すべて直列であるから，この場合 0 系 $2 \mathrm{C}$ の 2 入力も 断となり， 0 系 $2 \mathrm{C}$ は常に 0 相発振となる.よって 1 系の状態にかかわりなく $\mathrm{T}_{1}$ から制御信号が出るこ とはなく，この場合もフェイルセイフである。

\section{5. 定数監視回路・出力制御回路}

前章 Table 2 亿示した定数は, 定数パラメトロンの 出力を増幅したのち, 各素子に直列に供給されるこの であるが，これはフェイルセイフ性を保障する重要な 情報であるので，その量は常に一定範囲内にあるよう 監視される．Fig.9 亿差動増幅器を用いた監視回路の 一例を示す.定数素子の出力端子 $\mathrm{A}_{1}, \mathrm{~A}_{2}$ を通じ, 整 流後トランジスタ $\mathrm{Q}_{1}$ のベースに加えられる. $\mathrm{Q}_{1}, \mathrm{Q}_{2}$

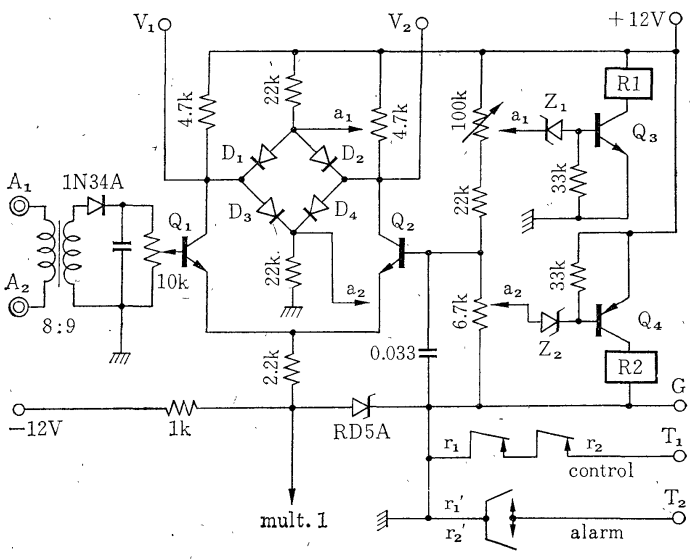

Fig. 9 Monitor circuit for the constant current of above fail safe element, where $Q_{1}$ to $Q_{3}$ are $2 \mathrm{SC} 267, \mathrm{Q}_{4} 2 \mathrm{SB} 227, \mathrm{D}_{1}$ to $\mathrm{D}_{4} 2 \times 1 \mathrm{~N} 34 \mathrm{~A}$, and $Z_{1}$ and $Z_{2}$ are $R D 6 A$

は差動形になって扔り，入力が標準値の場合は $\mathrm{V}_{1}$, $\mathrm{V}_{2}$ 点は同電位 $(6 \mathrm{~V})$ 伦保たれる。また $\mathrm{a}_{1}, \mathrm{a}_{2}$ 点は ツェナーダイオード $Z_{1}, Z_{2}$ によって $6 \mathrm{~V}$ 没定され ているから，ダイオード $\mathrm{D}_{1} \sim \mathrm{D}_{4}$ は断状態にある。こ のとき $\mathrm{Q}_{3}, \mathrm{Q}_{4}$ は通状態で, 電磁継電器, $\mathrm{R}_{1}, \mathrm{R}_{2}$ は作 動している. いま入力が標準值より下がった場合を考 えると, $V_{1}$ 点の電位は上升, $V_{2}$ 点の電位は下降する. このとき $D_{1}$ は逆方向で断, $D_{2}$ は順方向で通となり， $\mathrm{a}_{1}$ 点は $\mathrm{V}_{2}$ 点の電位に追従する。また $\mathrm{D}_{3}$ 通, $\mathrm{D}_{4}$ 断で あるから $a_{2}$ 点の電位は $V_{1}$ 点のそれに追従する。 こ こで入力が規定值より下がり， $\mathrm{V}_{1}$ 点で $8 \mathrm{~V}$ 以上, $\mathrm{V}_{2}$ 点で $4 \mathrm{~V}$ 以下になると, $Z_{1}, Z_{2}$ 惭状態となり, 乙 たがって $\mathrm{Q}_{3}, \mathrm{Q}_{4}$ 扮よび $\mathrm{R}_{1}, \mathrm{R}_{2}$ は断となり, $\mathrm{T}_{1}$ の地 気を去って制御を停止, $T_{2}$ を地気して警報を送出す る. ここで $\mathrm{R}_{1}, \mathrm{R}_{2}$ はいずれか一方が断になれば必要 十分であるが，安全のため二重構造とした.

次に入力が上年，規定値を越えた場合もまったく同 


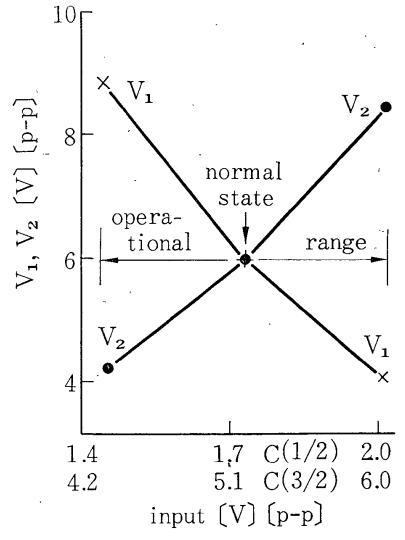

Fig. 10 Deviation of $V_{1}$ and $V_{2}$ level of above differential amplifier for input level

椂な過程を経て $\mathrm{R}_{1}, \mathrm{R}_{2}$ は断となる。ただし $\mathrm{V}_{1}, \mathrm{~V}_{2}$ 点の電位関係は逆転する. この差動增幅器の特性を Fig. 10 亿示した. 横軸の入力電圧が図の operational range 外飞出ると異常状態となる.ささ Fig. 9 の回 路では 1 素子の故障は問題ない。たと光ば $\mathrm{D}_{1} \sim \mathrm{D}_{4}$ の いずれか 1 つが断線, または $Z_{1}, Z_{2}$ の中の 1 つが短絡 しても監視機能は保持される。悉㤂 $Z_{1}, Z_{2}, Q_{3}, Q_{4}$ の 断はフェイルセイフとなる.ただ $\mathrm{D}_{1} \sim \mathrm{D}_{4}$ の短絡事故 は差動増幅器の機能を変じ好ましくないので，ダイオ 一ドを 2 個直列に用いた. しかし同時に 2 個の素子に 障害が生じた場合，たとえば $\mathrm{D}_{2}, \mathrm{D}_{3}$ あるいは $\mathrm{D}_{1}, \mathrm{D}_{4}$ が同時断, または $Z_{1}, Z_{2}$ 同時短絡の場合は監視機能 を失う。これを防ぐとは，信頼度の高い素子を用いる のはもちろんであるが，異常値を周期的に入力に印加 乙監視回路の機能チェックをする必要がある.

次に出力制御であるが，パラメトロン出力は小さい (1.6 Vp-p) ので増幅する必要がある. これも Fig. 11 に示すように二重系とし, Fig. 8 の出力端子 $\mathrm{T}_{1}, \mathrm{~T}_{2}$

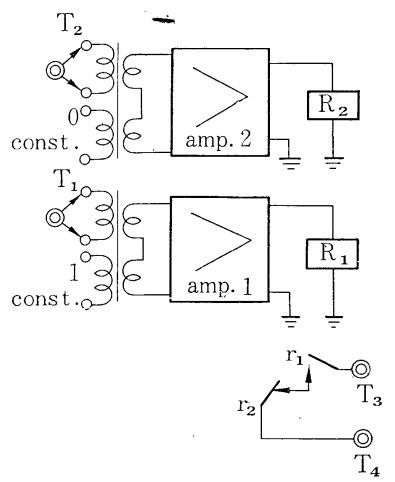

Fig. 11 Output control circuit whose terminals $T_{1}, T_{2}$ and $T_{4}$ are connected to $T_{1}$ and $T_{2}$ of Fig. 8 and $T_{1}$ of Fig. 9 respectively
をそれぞれ Fig. 11 の入力端子 $\mathrm{T}_{1}, \mathrm{~T}_{2}$ に接続する. 正常時 $\mathrm{T}_{2}$ 入力は 0 相電圧であるから, 定数 0 相電圧 飞加算され, amp. 2 打よび 電磁継電器 $\mathrm{R}_{2}$ は作動状 態にある.このとき Fig. 8 の $T_{1}$ すなわち Fig.11 の $\mathrm{T}_{1}$ が 0 相電圧 (非制御) ならば, 定数 $\pi$ 相電圧と 打消しあってなにごとも起きないが， $\mathrm{T}_{1}$ が $\pi$ 相電圧 (制御) となると入力電圧は倍加し,amp. 1 扤よび電磁 継電器 $R_{1}$ が作動し, 端子 $T_{3}$ から被制御機器に地気 を送出する. 異常のさいは端子 $\mathrm{T}_{1}$ に 0 相電圧，端子 $\mathrm{T}_{2}$ に $\pi$ 相電圧が現われ，定数とそれぞれ打消し， $\mathrm{R}_{1}$ は無作動, $\mathrm{R}_{2}$ は復㷌し, 端子 $\mathrm{T}_{3}$ から地気を送出する ことはない。また amp. 1，2 は正規の半分の入力（入 力巻線片側断を仮定）電圧では作動しない。すなわち， 出力制御るフェイルセイフ構造となっている.

\section{6. 総 合 特 性 ${ }^{7}$}

本素子の機能をチェックする意味で, Fig. 12 のブ

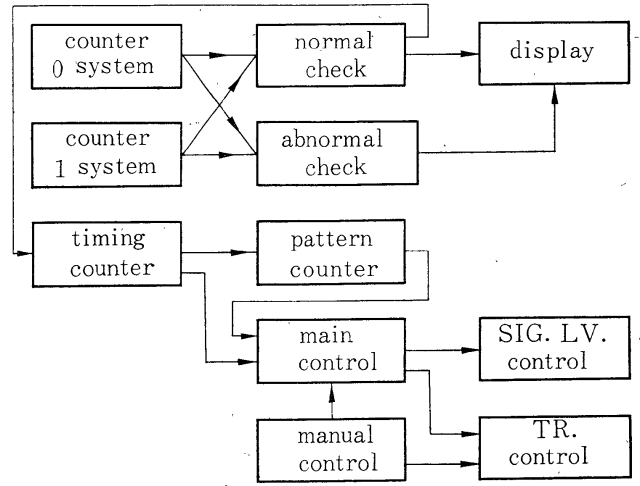

Fig. 12 Block diagram of test equipment using thin film fail safe elements

ロックダイアグラムに示す装置を試作した．小駅用列 車運行ダイヤ発生機能を有し, 一種の標準器として使 用するもので，誤った情報を送出しないよう，また大 形実用機への基礎データ集積の意味も含め，回路はフ エイルセイフ構成とした．論理動作は 3. 汇述べを素 子を用い, 最終出力は電磁継電器接点とする.

Fig. 12 に対しじゃっかんの説明を加兄るならば， 0 系，1系カウンタは本装置の基本クロックを生ずる部 分であり，一致検出回路とともに Fig. 8 にそのひな 型を示している. 異常検出回路は Fig. 9 に示す定数 監視装置で定数レベルを監視するとともに，定数断， 論理不一致を検出, 表示回路にその状沉を示す. 一致 検出回路よりの出力は表示回路の正常ランプを点燈す るとともに，タイミングカウンタおよびパターンカウ ンタで逓降し, 各出力から signal lever 制御パター ンを送出，これにしたがい，track 情報を列車運行ダ 


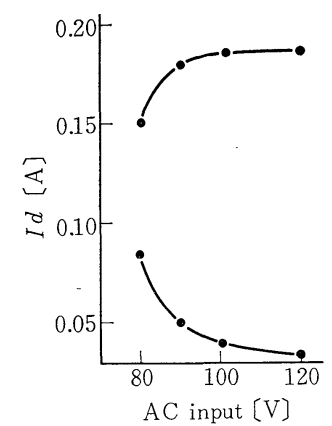

Fig. 13 Overall $I_{d}$ margin characteristic curves of the equipment for commercial line level, when $I_{2 f}=0.2$ Arms and $f_{m}=50 \mathrm{kHz}$

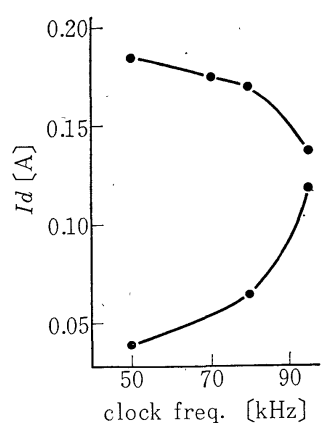

Fig. 14 Overall $I_{d}$ margin characteristic curves of the equipment for clock frequency $f_{m}$, when $I_{2 f}$ $=0.2 \mathrm{Arms}$
イヤに合わせ送出する. 使用素子 325 個, 電磁継電器 28 個が主部品である.

さて装置総合特性は, 商用電源, クロック周波数特 よび周囲温度の変化に対し，装置が正常動作を失らま での $I_{d}$ マージンを測定した. Fig. 13 はクロック周 波数 $50 \mathrm{kHz}$ ，励振電流 0.2 Arms に括ける, 商用電源 変動に対する $I_{d}$ マージン特性で，規格 $105 \pm 15 \mathrm{~V}$ を 十分満足している. Fig. 14 は励振電流 0.2 Arms を 固定し，クロック周波数を变化した場合の $I_{d}$ マージ ン特性で，条件さえ良ければ $80 \mathrm{kHz}$ まで使用可能で， あることがわかる. Fig. 15 に励振電流 0.2 Arms，ク

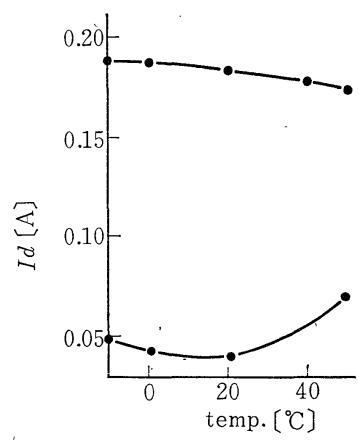

Fig. 15 Overall $I_{d}$ margin characteristic curves of the equipment for temperature, where $I_{2 f}=0.2$ Arms, and $f_{m}=50 \mathrm{kHz}$
ロック周波数 $50 \mathrm{kHz}$ に和ける，温度に対する $I_{d}$ マ ージン変化を示している. 規格 $20 \pm 30^{\circ} \mathrm{C}$ は十分に満 足している.

以上装置としての総合特性について述べたが，種々 の周囲変化を考慮すれば, 励振電流 0.2 Arms 前後, クロック周波数 $50 \mathrm{kHz}$ が安定した設定といえよう.

\section{7. むす び}

薄膜磁性線の応用として, 小形, 高速, 安定, 安価 を目標とするフェイルセイフ素子を開発，これを用い て一連の機能を有する試作機を製作，各種試験を試み た結果，安定性は十分であり，小形，安価の点も注ぼ 満足しうることがわかった：たた高速性はいまだ不十 分で，今後の課題である.さらにもら1つの特長を付 加するならば，フェイルセイフ素子としては，一種の パラメトロンを用意すれば良く，任意の論理回路はプ リント配線で別に作製できることであろう，最後に大 形実用機では，本文に現れた不都合な場合，たとえば 4. のフェイルセイフではあるが警報が出ない場合, または 5. の監視機能の停止などを検知するため，テ ストプログラムによる装置の定期的機能チェックを併 用しなければならないが，本稿の範囲外であるので省 いた.

本試作は鉄道技術研究所信号研究室の依頼により行 なったもので，御指導いただいた奥村，渡辺両氏に深 い感謝の意を表します。

\section{参考 文 献}

1）土屋：フェイルセイフ論理方式の研究, 電気試験所研究 報告第 695 号

2）渡辺漂か：パラメトロンによる準フェイルセイフ理論 系，信学会電計研資，p. 12/15 (1966)

3）奥村ほか：パラメトロンを用いた鉄道信号用連動装置， 信学会電計研資, EC 67-5

4）伊藤核か：薄膜磁性線の研究と矢の実用化報告, 信学会 電回材研凟, CPM 69-35

5）伊藤潘か：一軸暴方性を有する磁性薄膜の非線形性に関: する考察，信学会非線形研資，NLP 70-03

6）伊藤㴽か：薄膜パラメトロンを用いたフェイルセフ素 子, 44 年秋信学会全国大会 253

7）伊藤ほか：ワイヤパラメトロン・フェイルセイフ素子を 用いた試作機について，44 年電気関係東北支連大 $3 \mathrm{C}-8$, 